\title{
Pattern and Policies of Mainland China’s MICE Industry
}

\author{
Jianhua Wu, Xuan Xiao \\ Tourism School, Guang Dong University of Business Studies, Guangzhou, China \\ Email:wujianhua304@126.com, adelaxiao@126.com \\ Received June $7^{\text {th }}$, 2012; revised July 20 $0^{\text {th }}$, 2012; accepted August $13^{\text {th }}, 2012$
}

\begin{abstract}
China's MICE industry has witnessed rapid growth over the past decade. In the mainland China, however, its further development is affected by deficiencies in the planning and controlling policies. This short report will introduce the pattern of its MICE industry, discuss the merits and deficiencies of local and state-level policies, so as to explore directions for institutional improvement. The division of five econoimic zones was first put forward by Feng Jun (2006) with a view to promoting exhibition business in mainland China. The framework was later enriched by Zhang Wei, Vice Chairman of the China Council for the Promotion of International Trade. This short report illustrates the detailed features of each economic zone, as well as their incentive policies, with the hope of helping the local and central governments in their policy-making for MICE industry.
\end{abstract}

Keywords: Patterns of Mainland China’s MICE Industry; Incentive Policies; Policy Features

\section{The Basic Pattern and Features of Mainland China's MICE Industry}

\section{Basic Pattern}

Since Reform and Opening-up, mainland China's MICE industry has developed fast and formed five economic zones, namely, Bohai Sea Circle, Yangtse-River Delta, Pearl-River Delta, Northeast China Region, and Central-West China Region.

Zone 1: Bohai Sea Circle, including Beijing, Tianjin; Qingdao, Jinan, Yantai, Weifang, and Weihai in Shandong Province; Shijiazhuang, Tangshan, Langfang in Hebei Province, etc, with Beijing as the core. This early-developed zone features abundant large-scale players, and highly-specialized and internationalized exhibitions. It brags about a cluster of famous MICE brands. Beijing is the headquarter of numerous state-level scientific organizations and industrial associations, which endows the city with incomparable advantages in industrial specialized technology exhibitions. There are 22 UFI certified exhibition brands in mainland China, and nine of them are in Beijing, such as CIMT (China International Machine Tool Show), CITME (China International Textile Machinery Exhibition), P\&T/ EXPO COMM CHINA, CHIC (China International Clothing \& Accessories Fair), China Refrigeration, BICES (Beijing International Construction Machinery Exhibition and Seminar), Metallurgy China, ChinaMed (International Medical Instruments \& Equipment Exhibition) and China Print.

Zone 2: Yangtse-River Delta, including Nanjing, Suzhou and Nantong in Jiangsu Province, Hefei in Anhui Province, Ningbo, Wenzhou, Yiwu and Hangzhou in Zhejiang Province, with riverside cities as one wing, and coastal cities as the other. Ningbo and Wenzhou focus on manufacturing exhibitions; Suzhou is concentrated on foreign-trade and foreign-fund exhibitions; Hangzhou positions itself as a composite destination for leisure, meetings and sightseeing. Thanks firstly to a good start, secondly to the commitment of local governments, and thirdly to the rational planning of MICE projects, this zone is fairly dynamic, with its great potential mostly based on geographic advantages and proper industrial structure.
Zone 3: Pearl-River Delta, covering Guangzhou, Shenzhen, Dongguan, Shunde, Zhuhai and Zhongshan in Guangdong Province, and Fuzhou, Xiamen in Fujian Province, with Guangzhou as the core ${ }^{1}$. This zone is highly modernized and globalized, featuring distinguished MICE industrial structure. The exhibition distribution there shows obvious geographic and industrial concentration. Another distinguished feature of the zone is its keen "coopertitions" with Hongkong and Macao, which has been greatly prompted by the implementation of CEPA (Closer Economic Partnership Arrangement) scheme. Hongkong, Shenzhen and Guangzhou enjoy solid industrial basis, convenient transportation and developed logistics, which endow them with the statuses of the zone's top three international exhibition centres.

Zone 4: Northeast China Region, including Dalian, Changchun, Harbin, Shenyang and Jilin, with Dalian as the leading city. This zone is adjacent to Russia, South Korea and North Korea, so it utilizes geographic advantage to develop Russia-oriented or Korea-oriented trade fairs. It also takes advantage of its strength in heavy industry to hold relative exhibitions, such as International Automobile Fair in Chuangchun, International Equipment Manufacturing Expo in Shenyang, CIGF (China International Garment \& textile Fair) in Dalian, etc.

Zone 5: Central-West China Region, including Chongqing and Chengdu in Sichuan Province, Zhengzhou in Henan Province, Wuhan in Hubei Province, Changsha in Hunan Province, Xi'an in Shaanxi Province, Kunming in Yunnan Province and Nanning in Guangxi Province. This zone tends to foster exhibition brands with regional characteristics, such as Western China International Fair in Chengdu, CCHTF (Chongqing Hi-Tech Fair) in Chongqing, China East-West Region Cooperation, Investment \& Trading Fair in Xi'an, CAEXPO (China-ASEAN Expo) in Nanning, etc.

\footnotetext{
${ }^{1}$ Hongkong and Macao Special Administrative Regions are traditionally regarded as part of the zone. They are omitted here for the mere purpose of focusing our discussion on mainland China's MICE industry.
} 
Expos distribution in various MICE economic zones in 2008 is displayed in Figure 1.

\section{Features of the Pattern}

We observe from the following aspects:

Geographic distribution: Five MICE economic zones are beginning to take shape with each being centered by a major metropolitan as its core. However, some zones are rather nominal. By that we mean some cities are classified into the same zone just because of their geographic adjacency, but not because of the interactions or linkages among them.

Characteristics of MICE cities: Based on local industrial resources, the five zones have stepped into their initial stage of interactive and multi-tier pattern. Yet none of the zones has fostered distinguished features, not to mention irreplaceable competence.

Drives of MICE industry: Although each zone has some well-known exhibition brands, none of them has dominant power. Hence the drive of central MICE metropolitans to satellite cities is too weak to form competitive urban clusters.

Industrial distribution: MICE industry in first-tier cities is booming; that in second-tier cities, sprouting; while in while small or remote cities, it barely exists.

Developing mechanism: Generally speaking, the MICE economy centres in the Chinese mainland are governmentinitiated (for example, the Central-West China Region was formed during the course of Western Development), which results in poor linkage and coordination among these zones. Blind competitions frequently occur even between cities in the same zone.

\section{Mainland China's Incentive Policies for MICE Industry}

\section{Central Government’s Incentive Policies}

\section{Examination and Approval System}

China formulated the Management Measures for the Examination and Approval of Holding Economic and Trade Exhibition

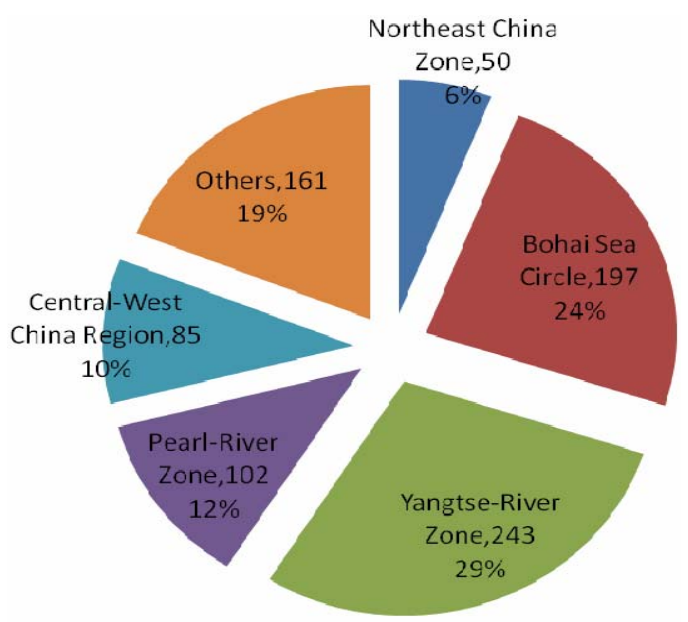

Figure 1.

Expos distribution in MICE economic zones, 2008².

${ }^{2}$ Data source: WANG Fanghua, GUO Jurong (2009). Blue Book of Convention \& Exhibition Economy (2009). China: Social Sciences Academic Press.
Abroad, and commanded that all exhibitions held in abroad be examined and approved by CCPIT (together with Ministry of Commerce of PRC). This policy can be summarized as "strictly control to avoid repetitive holding of exhibitions; encouraging joint organizing; preference to large-scale, influential, highquality and periodical exhibitions; preference to professional and experienced organizers." An economic and/or technological exhibition by an external agency must be either jointly held with a legal person qualified for hosting such an exhibition within the territory of China or simply entrusted to such a legal person.

\section{Financial Support for Market Expansion}

The State Economic and Trade Commission has set up a fund for medium-and small-scaled enterprises to explore international markets. It comes from Central Foreign Trade Development Fund, which is divided into two parts: one for central government and the other for local government.

\section{Local Governments’ Incentive Policies}

\section{Positioning and Objectives of MICE Industry}

There are 31 provincial-level administrative regions in mainland China, among which 29 have identified specific objectives for MICE economy in their Eleventh Five-Year Plan. Key MICE cities have specified the orientations and objectives for their MICE industry. For example, Beijing positions MICE industry as "one pillar industry of the third industry", with an objective "to become China's primary city for political, cultural and tech conventions \& exhibitions as well as a key Asian city for famous MICE brands on international trade, social environment, tech \& culture”. Shanghai positions it as “a key component of service industry, a new industry to enhance their city image, improve municipal services and prompt economic \& social development". Their goal is "to become one of the key MICE cities of Asia-Pacific region in 2010, with MICE industry accounting for $0.2 \%$ of GDP”. Guangzhou positions it as "an important part of modern service industry", and they aim "to be a central city for international conventions \& exhibitions”. In short, the first-tier MICE metropolitans (e.g. Beijing Shanghai, Guangzhou and Shenzhen) aim to be the key MICE cities in Asia or Asia-Pacific area; and second-tier MICE cities (e.g. Hangzhou, Nanjing and Dalian) aim to be national or regional key MICE cities. These objectives are fairly down-toearth, with diversified focuses so as to avoid blind competitions to a certain extent.

\section{Incentive Modes}

Priority in Development Planning: e.g. Beijing has announced that MICE industry is one of its six key modern service industries with high priority in its $11^{\text {th }}$ five-year planning. Hangzhou gives priority to MICE industry over economic development and traditional tourism sectors.

Financial Support, Capital Aid or Award: The content and modes of financial support vary from one region to another. Some metropolitans (such as Beijing, Shanghai, Hangzhou, Ningbo, Dongguan and Xi'an) have established exclusive funds to support MICE industry, with incentives consolidated as municipal financial subsidies. These exclusive funds are mainly expended on exhibition orientations, exhibitors' allowance, and propaganda. Other cities only grant allowance to listed exhibi- 
tions.

Taxation Preference: Take Shanghai for instance. Shanghai Local Tax Bureau released Circular on Issues Regarding Levy of Business Tax on Conference \&. Exhibition Industry in Shanghai (\# 49 [2008], valid since September 1, 2008), which ensured preferable taxation on MICE industry. For example, it's stipulated that for the sponsors or organizers, business tax shall be levied on the revenue excluding (venue) rental, construction fee, advertisement fee, accommodation fee, admission and transportation fee paid to the third party.

Encouraging Personnel Training: This is practiced for such a three-fold purpose as, first, to enhance the development of academic and vocational education, so as to improve the quality of human resource (for instance, Beijing encourages academies to set up MICE-related specialties at both undergraduate and postgraduate levels; second, to launch various training programs (for example, Xi'an set up Qujiang International MICE Training Center, and offers various MICE training programs free of charge for the local enterprises); and third, to send some staffs to study abroad and to introduce foreign experts, so as to improve management skills and visions.

\section{Preference of Incentive Policies}

The key MICE cities all prefer exhibitions \& conferences that can invigorate local economy. Preference is given to the exhibitions and conferences with following characteristics:

Coincident with Local Industrial Development Objectives: For instance, Beijing has a preference for well-known exhibitions and conferences coincident with its strategy for industrial development and Olympic economy.

Of Well-known Brand or with Specialty: Hangzhou develops its MICE industry toward mareketization, specialization, internationalization, and branding, advocating "comfortable life, rich culture and successful business" and highlighting its unique scenery and culture advantage. Shenzhen offers temporary financial aid to well-known exhibitions and conferences in case of occasional dilemmas due to non-resistance or fierce competitions from outside the region. Financial aids are also provided to key projects in the initial stage, or when they fail to reach a break-even point with enlarged scales.

With international partnership: e.g. in Beijing, MICE enterprises are encouraged to participate in exhibitions and conferences held in developed countries or regions in order to learn their expertise and skills. Shanghai also intensifies exchanges and cooperation with worldwide leading organizations and companies to seize on the latest trends in MICE industry. Specifically, Shanghai encourages world organizations, associations, cities and multi-national corporations to hold annual meetings, forums, trade fairs and other MICE activities in Shanghai. At the same time, the city of Shanghai takes an active part in overseas market expansion (e.g. exhibitions in Saudi and Indonesia are fairly successful).

\section{Standardizing Administration, Which Includes:}

a) To Set Up Administrative Institutions: e.g. Shenzhen has set up a "Convention \& Exhibition Industry Development Coordinating Office" to supervise the related planning and policies, oversees state-owned venues and coordinate large-scale activities. Many efforts have been made to explore an effective administrative system of MICE industry. For instance, Shanghai's Action Plan for the Development of MICE Industry suggests that "joint-meeting system should be set up to decide the strat- egy, planning and policy of MICE industry, and to support coordinated problem solving." Shenzhen's $11^{\text {th }}$ Five-Year Plan also suggested that consultant committee should be established to give advice on decision-making and to solve disputes.

b) To Offer Auxiliary Services: e.g. Beijing has established a "green path” for MICE industry. It reforms administrative system, simplifies market entry formalities, gradually restructures its administrative system (administrative rights transferring from multi-departments to local industrial associations) and reforms market access control (from restrictive mode to market-oriented mode). Xi'an has set up "Qujiang MICE Service Center” to provide non-stop services, such as Customs declarations, railway transportations, and delivery services, etc.

\section{A Summary of Mainland China's Incentive Policies for MICE Industry}

From the above, we can summarize mainland China's incentive policies from the following aspects:

\section{Position of MICE Industry in National Economy}

The planning of MICE industry is somehow neglected in state-level planning - it was only mentioned in the planning of cultural industry, which indicates that government hasn't recognized the comprehensive influence of this industry. It was again neglected in the Outline of China's $11^{\text {th }}$ Five-Year Plan ${ }^{3}$. The lack of state-level planning and strategic positioning has resulted in the weak overall control and poor coordination of MICE industry in various regions.

\section{Administrative Mechanism of MICE Industry}

The state hasn't designated a unified administrative authority for MICE industry. Local governments, venues, associations and financial institutions all have rights to examine, and grant approval to MICE projects, which caused serious problems of multi-administrations and blind repetitions. Exhibitions \& conferences are supervised by different departments according to their themes and regions (overseas or domestic). Take "international exhibitions” for instance, they can be examined and approved by three departments: the Ministry of Foreign Trade and Economic Cooperation, the Ministry of Science and Technology and CCPIT (China Council for the Promotion of International Trade).

\section{Administrative Mode of MICE Industry}

The administrative mode of MICE industry is imprinted with the planned economy, which is well embodied by its examining and approving system.

\section{Policy System of MICE Industry}

In mainland China, policies and regulations of MICE industry are made individually by local governments: e.g. Beijing released Development Plans of Beijing's MICE Industry (2004-2008); Hangzhou released Hangzhou's $11^{\text {th }}$ Five-YearPlan of MICE Industry (2006-2010); Dalian released Dalian's $11^{\text {th }}$ Five-Year-Plan of MICE Industry, etc. The lack of a unified administrative authority remains a large obstacle to further development.

${ }^{3}$ It is the blueprint of China's economic and social development (20062010), with guiding principles and development goals for each key sector of the nation. 


\section{Efforts to Support MICE Industry}

The state's support to MICE industry is rather limited. The State Economic and Trade Commission's market exploring fund is the only state-level supportive project. Only a small part of the fund is used to support medium-and small-scaled enterprises to explore international markets (exclusive to exhibition fee, exhibition installation fee and freight charge for large exhibits).

\section{Preference of Incentive Policy}

Mainland China's MICE industry is still in its initial stage. The key MICE cities are in a period of expansion, during which their preference is given to projects and companies of largescales. Take Dalian for example, its exclusive fund only focuses on the following: 1) national exhibitions and conferences organized by ministries and commissions that would take up a space of over $10,000 \mathrm{~m}^{2}$; 2) exhibitions and conferences jointly organized by domestic companies and well-known foreign counterparts and occupying a space over $10,000 \mathrm{~m}^{2}$; and 3) specialized exhibitions with local characteristics with a history of more than 10 successful editions, and taking up a space over $20,000 \mathrm{~m}^{2}$. All this indicates that more support is required to help the SMEs and young enterprises in the MICE industry.

\section{REFERENCES}

Feng, J. (2006). On China's MICE economic zones. China Conference
\& Exhibition, 1, 23-25.

Financial Bureau of Beijing (2006). Notice on the exclusive fund for Beijing's cultural \& creative industry. No. 2731. Beijing, PRC: Beijing Municipal Government Printing Office.

Ministry of Foreign Trade and Economic Cooperation (2001). Detailed rules for the implementation of the measures for administration of international market developing funds of small-and medium-sized enterprises (for provisional implementation). No. 270. Beijing: Chinese Government Printing Office.

Ningbo Municipal Government (2007). Notice on prompting the construction of Ningbo international conference exhibition center. No. 60. Ningbo, PRC: Ningbo Local Government Printing Office.

Ningbo Municipal Government (2008). Notice on prompting Ningbo's MICE industry. No. 45. Ningbo, PRC: Ningbo Local Government Printing Office.

Shanghai Local Tax Bureau (2008). Circular on issues regarding levy of business tax on conference \& exhibition industry in Shanghai. No. 49. Shanghai: Shanghai Municipal Government Printing Office.

Shanghai Pudong New Area Economic Committee. Notice on subsidies for MICE tourism development of Pudong new area. http://www.mice.pudong.gov.cn/

Shenzhen Municipal Government (2004). Notice on prompting Shenzhen's MICE industry. No. 66. Shenzhen, PRC: Shenzhen Local Government Printing Office.

Wang F. H., \& Guo J. R. (2009). Blue book of convention \& exhibition economy. China: Social Sciences Academic Press.

Xiamen Municipal Government (2003). Notice on prompting Xiamen's MICE industry. No. 111. Xiamen, PRC: Xiamen Local Government Printing Office. 